Academic City University College - Accra Ghana

Society for Multidisciplinary \& Advanced Research Techniques (SMART) Africa

Tony Blair Institute for Global Change

FAIR Forward - Artificial Intelligence for All - Deutsche Gesellschaft für Internationale Zusammenarbeit (GIZ) GmbH

Accra Bespoke Multidisciplinary Innovations Conference (ABMIC)

\title{
Evaluation of the Potability of Water Sources in Yakurr Local Government Area of Cross River State, Nigeria
}

\author{
${ }^{1}$ Bassey E. Agbo*, 2Francisca Adie, ${ }^{1}$ Atoyebi B. Abdulraheem, ${ }^{3}$ Daniel O. Etim \\ $\&{ }^{1}$ Grace 0 . Daniel \\ 1\&2Department of Microbiology \\ 3Botany Department \\ University of Calabar \\ Calabar, Nigeria \\ E-mail: beagbo@unical.edu.ng \\ Phone: $+234(0) 7031127120$
}

Member Proceedings Citation Format

Bassey E. Agbo, Francisca Adie, Atoyebi B. Abdulraheem, Daniel O. Etim \& Grace O. Daniel (2021): Evaluation of the Potability of Water Sources in Yakurr Local Government Area of Cross River State, Nigeria. Proceedings of the Accra Bespoke Multidisciplinary Innovations Conference. University of Ghana/Academic City University College, Accra, Ghana. December 2021. Pp 111-126. www.isteams.net/ghanabespoke2021. DOI https://doi.org/ 10.22624/AIMS/ABMIC2021-V2-P9 


\title{
Evaluation of the Potability of Water Sources in Yakurr Local Government Area of Cross River State, Nigeria
}

\author{
Bassey E. Agbo, Francisca Adie, Atoyebi B. Abdulraheem, Daniel O. Etim \\ \& Grace 0. Daniel
}

\begin{abstract}
Studies on the bacteriological and physico-chemical characteristics of different water sources in Yakurr, Cross River State, Nigeria was carried out using American Public Health Association standard procedures for physico-chemical analyses of water and standard biochemical and microbiological protocol for the analysis of water for faecal and total coliform enumeration. Average temperature, $\mathrm{pH}$, turbidity and conductivity of the samples ranged from $26.90 \pm 0.02^{\circ} \mathrm{C}-27.88 \pm 0.02^{\circ} \mathrm{C}$; $5.00 \pm 0.02-6.38 \pm 0.03 ; 3.05 \pm 0.01 \mathrm{NTU}-30.41 \pm 0.01 \mathrm{NTU}$ and $29.01 \pm 0.01 \mu \mathrm{s} / \mathrm{cm}-72.76 \pm 0.01 \mu \mathrm{s} / \mathrm{cm}$ respectively. $\mathrm{BOD}_{5}$, TDS and iron concentration ranged from $6.00 \pm 0.02 \mathrm{mg} / \mathrm{l}-10.69 \pm 0.01 \mathrm{mg} / \mathrm{l}$; $18.24 \pm 0.01 \mathrm{mg} / \mathrm{l}-43.63 \pm 0.03 \mathrm{mg} / \mathrm{l}$ and $0.32 \pm 0.01 \mathrm{mg} / \mathrm{l}-1.51 \pm 0.01 \mathrm{mg} / \mathrm{I}$ respectively. Total coliform count of the sample from Kesekpang-Ekori had the highest value of $78.00 \pm 3.61 \mathrm{cfu} / 100 \mathrm{ml}$, followed by Sokol-Ugep and Mgbeke-Mkpani samples with values of $62.00 \pm 3.00 \mathrm{cfu} / 100 \mathrm{ml}$ and $38.33 \pm 2.52 \mathrm{cfu} / 100 \mathrm{ml}$ respectively. The sample from Nkinforna had the least coliform count of $10.00 \pm 2.00 \mathrm{cfu} / 100 \mathrm{ml}$. Sample from Ekori River had the highest THBC value of $2.13 \pm 0.31 \times 10^{6} \mathrm{cfu} / \mathrm{ml}$, Kesekpang-Ekori and Sokol-Ugep samples had $1.10 \pm 0.17 \times 10^{6} \mathrm{cfu} / \mathrm{ml}$ and $1.03 \pm 0.06 \times 10^{6} \mathrm{cfu} / \mathrm{ml}$ respectively. Mgbeke-Mkpani sample had the least valve of $7.00 \pm 1.00 \times 10^{5} \mathrm{cfu} / \mathrm{ml}$. A total of nine bacterial species were isolated, they were Pseudomonas aeroginosa, Escherichia coli, Bacillus subtilis, Proteus vulgaris, Serratia maecesen, Staphylococcus aureus, Salmonella spp., Enterobacter cloacae and Micrococcus leteus. The study had revealed a high level of poor quality sources of water in Yakurr and makes need for urgent health intervention by relevant body.
\end{abstract}

Keywords: Potability, water quality, bacteriological quality, physico-chemical characteristics and total coliform count

\section{INTRODUCTION}

All organisms requires water for life sustenance. Water is one of the most abundant commodities since it occupies about $70 \%$ of the earth's surface ${ }^{1}$. Water is the most essential product that is taken by humans which must be prevented from deterioration in quality. It is also essentials for life and life has evolved in water due to its unique chemical and physical properties ${ }^{2}$. Okorafor et al,1 highlighted his point of view when they declared that "water functions in a variety of ways within a cell" can't be debated. Life originated from water, it is the matrix of life and it's also a solvent and medium. Water is also the medium by which diseases such as typhoid fever, dysentery and cholera can be spread from one human to another" 2, 3 . Treatment are performed to remove pathogenic micro-organism and also decrease turbidity, eliminate taste, odour, remove nuisance chemicals, such as manganese or iron and soften the water to make it more useful for consumption, laundry and other industrial processes ${ }^{4}$. Water is that unique substance that is made-up of hydrogen and oxygen elements, it exist in gaseous, liquid and solid states. 
Water is the most abundant and essential of compounds. It's a liquid at room temperature, odourless and tasteless, it can dissolve many other substances, the versatility of water as a solvent is of great importance to living organisms ${ }^{1,5}$. Good water quality for human consumption must therefore be potable or whole some which must be free from odour, colours and turbidity ${ }^{1}$. These physical characteristic of water are easily noticed by a consumer. A part from these physical qualities, chemical quality of the water also calls to mind since chemical analysis is indispensable for eliminating such dangers as the presence of poisonous metals, bad solvency, radioactive elements and other harmful substances. Therefore, all potable water must be free from harmful micro-organisms and must neither deteriorate in distributing system nor storage tanks. It must not also attack or corrode the distribution system ${ }^{1,2,6}$.

The presence of excrete in water sheds can lead to contamination of both impounded and shallow ground waters-supplies. Water may also be contaminated directly by dumping of untreated or inadequately treated waste and effluent ${ }^{7}$. A variety of pathogenic microorganism may be locally shed and find their water into water supplies in sufficient numbers. Among the most commonly encountered are enteric bacilli such as Salmonella and Shigella, cholera Vibrios, animal parasites, including Ascaris, Entamoeba and Glardia also Enteroviruses such as Polio viruses, Consackle viruses and Eacho viruses ${ }^{1,2 .}$

There are several micro-organisms commonly found in human and other animal intestinal tracts that can be used as indicators of faecal pollution. Their presence in water supplies in sufficient numbers signals contamination of an intestinal source. The most of these indicator organisms are the coliforms ${ }^{1,8}$. The fact is that contamination of water is hazardous to life cells whether it's for drinking, recreational, agricultural or industrial purpose. The suitability of water supply is determined by physical, chemical, biological that offers the most delicate test for detection of faecal pollution ${ }^{1,2,9}$.

Water quality analysis is the standard procedure that aimed at the detection of specific pathogens in contaminated water. This is a possible task, however, it is often impracticable because of certain reasons. The researcher stands the risk of being infected by the pathogen, the number of pathogens present is generally so small in comparison with the normal intestinal bacteria that may be excreted into water sporadically. Therefore, the isolation of pathogens will involve examination of large volume of water may need the application of selective media and their identification may require varied and complex biochemical and serological test. In order to avoid the problems of delayed processes, it is significant that modern sanitary practices including bacteriological assessment of water quality, chlorination of potable water supplies, and adequate treatment and disposal of sewage have virtually eliminated large scale epidemic of enteric infections in developed nations ${ }^{1,2,9,10 .}$

Water is an essential product that is consumed by humans, animals and plants alike, as such it must be kept safe and prevented from deterioration in quality. The potability of drinking water sources becomes even more important as water borne diseases spread through it. This research will evaluate the potability of drinking water sources in Yakurr Local Government Area of Cross River State, Nigeria having in mind the physical, chemical and microbiological parameters that plays a significant role in determining the potability of drinking water. 


\section{MATERIALS AND METHODS}

\subsection{Study Area}

The water samples for the research work were collected from different sources in Yakurr local government area, Cross River State, Nigeria. Yakurr is located at the central senatorial district of Cross River State, Nigeria. Yakurr is made up of seven (7) villages which consists of a number of people. The main occupation of the people is farming, civil servant and a few are traders. The sampling sites are all located at various village settlements within Yakurr local government area. They make use of this water though not minding whether the water is potable for consumption or not. The five (5) water samples collected in Yakurr LGA, Cross River State, Nigeria were from Sokol Ugep stream, Nkinforna Assiga stream, Mgbeke Mkpani stream, Ekori River and Kesepang Ekori spring among others provide water for drinking and domestic use to members of the local communities. The water samples are not treated and hence may not meet up the WHO standard.

\subsection{Sample Collection}

i. $\quad$ Sokol Ugep stream: The water is owned by Ugep community and is located between Ugep and Ekori community of Yakurr LGA, Cross River State, Nigeria. The samples were collected at a point where the community take their bath, washing of clothes is done by the villagers and also use for domestic use by the villagers. In that cases the water is exposed to all kinds of contamination.

ii. Mgbeke Mkpani stream: The water is located between Ekori and Mkpani community and it is owned by Mkpani community. The samples were collected at a point where the villagers used to fetch their water for domestic use taking their bath and washing of clothes by the members of the community. The water is exposed and it is open in that reason it can readily be contaminated by their dirty hands, clothes or organisms from their body etc.

iii) Nkinforna Assiga stream: The water samples were collected at a point where the villagers normally fetch their water for domestic use. Also the point is used for washing of clothes and taking of bath by members of the local community with this, it is expected that the water can be contaminated by the dirty clothes or organisms from the body of those people who take their bath in the stream.

iv) Ekori River: This River is owned by Ekori community, it is located at a point where washing of clothes is done by villagers. The villagers do take their bath there, few cases of faecal contamination had been reported by the villagers .

v) Kesepang Ekori: This water is lined by bricks to obtain water from underground water. It is owned by Ekori village and is the main source of water for both drinking and domestic use for the village. The water is exposed to all source of contamination from the rope used to fetch the water by the villagers.

\subsection{Physicochemical Analysis of Water Samples}

\subsubsection{Temperature}

This was measured with the aid of a thermometer. The thermometer was inserted into the water sample in a beaker and the temperature reading was taken down 2, 11, 12, 13, 14 .

\subsection{2 $\mathrm{pH}$}

The $\mathrm{pH}$ values of the water samples were measured with a $\mathrm{pH}$ meter with model number: Mettler Toledo MP 220. The pH meter probe was inserted into the water sample in a beaker, the READ key was pressed and the $\mathrm{pH}$ reading was noted $2,11,12,13,14$. 


\subsubsection{Turbidity}

A turbidity meter of the model number: HANNA INSTRUMENT H193703 was used for this analysis. The water sample was placed in the turbidimeter bottle and the bottle wiped clean with a cloth to erase finger prints on the sample bottle that may affect the reading. The bottle was then placed on the turbidimeter and the READ key pressed, the turbidity reading was then displayed $2,11,12,13$.

\subsubsection{Conductivity}

Conductivity meter of the model number: HANNA INSTRUMENT H18733 was used for this analysis. The conductivity meter probe was first rinsed with distilled water and inserted into the water sample in a beaker, the conductivity reading was displayed 2, 11, 12, 13, 14 .

\subsubsection{Aluminium}

Five millilitres $(5 \mathrm{ml})$ of the water sample was placed in a test tube and 1 micro-spoonful of Al$1 \mathrm{~A}$ reagent was added and shaken to dissolve. $1.20 \mathrm{ml}$ of aluminium reagent $\mathrm{Al}-2 \mathrm{~A}$ and $0.6 \mathrm{ml}$ of reagent Al-4A was added and mixed. The mixture was allowed for 2 minutes before reading out the aluminium concentration using the spectrophotometer 2, 11, 12, 13.

\subsubsection{Ammonia}

This was carried out using the colorimetric method. Ten millilitres $(10 \mathrm{ml})$ of the water sample was placed in a calibrated plastic cup, 2 drops of ammonia reagent 1 and 8 drops of ammonia reagent 2 (Nessler solution) were each added to the water sample and mixed well. After 5 minutes, the solution was poured into the colorimetry tube and the nearest colour match was used to determine ammonia concentration in the water sample 1,2,11,13.

\subsubsection{Calcium}

Spectrophotometry method was used, $0.10 \mathrm{ml}$ of the sample was placed in a test tube using pipette and $0.50 \mathrm{ml}$ of calcium reagent Ca-1 was added and mixed properly. $0.40 \mathrm{ml}$ each of calcium reagent $\mathrm{Ca}-2$ and $\mathrm{Ca}-3$ were also added to the test tube and mixed well. The mixture was allowed for eight minutes to give full colour development and then filled into a reaction cell placed in the spectrophotometer where the calcium concentration was displayed 1, 2, 7, 11, 12, 13.

\subsubsection{Ammonium}

Spectrophotometry method was used for this analysis in which five millilitres $(5 \mathrm{ml})$ of the water sample was placed in a pre-labelled test tube and $0.60 \mathrm{ml}$ of ammonium reagent $\mathrm{NH}_{4}-1$ was added using a syringe. 1 level micro-spoonful of ammonium reagent $\mathrm{NH}_{4}-2$ was also added, shaken and allowed for 5 minutes. Ammonium concentration was determined at a wavelength of $520 \mathrm{~nm}$ in the spectrophotometer 2,15 .

\subsubsection{Copper}

Five millilitres $(5 \mathrm{ml})$ of the water sample was placed in a reaction cell and $0.50 \mathrm{ml}$ of copper reagent $\mathrm{Cu}-1 \mathrm{k}$ was added to the water sample and mixed. Five minutes was allowed to elapse before copper concentration was read from the mixture $2,7,11,13$.

\subsubsection{BOD}

BOD meter (Model: HACH HQ4OD) was used to determine this parameter. The meter probe was first of all rinsed with distilled water before it was inserted into the water sample. BOD reading was displayed on activation of the read key 2, 11, 12, 13, 14 . 


\subsubsection{Chloride}

Spectrophotometry method was also used for this analysis in which five millilitres $(5 \mathrm{ml})$ of the water sample was placed in a pre-labelled test tube and $2.50 \mathrm{ml}$ of chloride reagent $\mathrm{Cl}-1$ was added to the water sample and mixed well. Chloride reagent $\mathrm{Cl}-2$ was equally added, shaken and allowed for 1 minute before reading out the chloride concentration from the spectrophotometer at a wavelength of $460 \mathrm{~nm}^{2,11,12,13 .}$

\subsubsection{Iron}

Spectrophotometry method was used for this analysis: five millilitres $(5 \mathrm{ml})$ of the water sample was placed in a pre-labelled test tube and $0.30 \mathrm{ml}$ of iron reagent Fe- 1 was added to the sample, shaken and allowed for 3 minutes. The iron concentration in the water sample was there after read at a wavelength of $420 \mathrm{~nm}$ in the spectrophotometer 2, 7, 11, 12, 13 .

\subsubsection{Fluoride}

Spectrophotometry method was also used for this analysis: five millilitres $(5 \mathrm{ml})$ of the water sample was placed in a reaction cell and 1 dose of fluoride reagent $\mathrm{F}-1 \mathrm{~K}$ powder was added to it, shaken and the fluoride concentration read at a wavelength of $620 \mathrm{~nm}$ using a spectrophotometer 2, 11, 12, 13.

\subsubsection{Nitrogen}

Spectrophotometry method was used, $5 \mathrm{ml}$ of the water sample was placed in test tube and 1 micro-spoonful of nitrite reagent $\mathrm{NO}_{2}-\mathrm{AN}$ was added to it and shaken well to dissolve. Ten minutes was allowed to elapse before noting the nitrite concentration in the water sample. This reading gives nitrite value and to get the nitrogen value, the nitrite value is multiplied by a constant 0.3045. Therefore nitrogen is $\mathrm{NO}_{2} \times 0.3045$ 2, 7, 12, 14 .

\subsubsection{Sulphate}

Spectrophotometry method was used for the analysis in which two and a half millilitres $(2.50 \mathrm{ml})$ of the water sample was placed in a pre-labelled test tube and $0.20 \mathrm{ml}$ of sulphate reagent $\mathrm{SO}_{4-}$ $1 \mathrm{~A}$ added to it and mixed properly. One level spoonful of sulphate reagent $\mathrm{SO}_{4}-2 \mathrm{~A}$ powder was also added and mixed well. The solution was kept in a water bath at $40^{\circ} \mathrm{C}$ for five minutes, after which $2.50 \mathrm{ml}$ of sulphate reagent $\mathrm{SO}_{4}-3 \mathrm{~A}$ was added, mixed well again and the solution filtered using Whatman No. 1 filter paper.

The filtrate was then mixed with $0.40 \mathrm{ml}$ of sulphate reagent $\mathrm{SO}_{4}-4 \mathrm{~A}$. The solution was again kept in a water bath for seven minutes at $40^{\circ} \mathrm{C}$. This was transferred to a round cell and placed in the spectrophotometer to read off the concentration of sulphate in the water sample at a wavelength of $520 \mathrm{~nm}^{2,11}, 12,13$.

\subsubsection{Manganese}

Multi-cell adapter with I-inch square cell holder was inserted in the electronic device after the "manganese" test was selected from a button. Then a square sample cell was filled with $10 \mathrm{ml}$ of the sample. Contents of one buffer powder pillow, citrate type of manganese stopper was added. Then contents of one sodium periodate powder pillow was added to the sample cell stopper and inverted to mix. The development of violet colour indicated the presence of manganese $2,13,16$. 


\subsubsection{Phosphorus}

A square sample cell was filled with $10 \mathrm{ml}$ of the water sample. The blank was inserted into the cell holder. The ZERO mark was pressed on the button, with the display showing $0.00 \mathrm{mg} / \mathrm{I} \mathrm{PO}_{4}{ }^{3-}$ The prepared sample was wiped and inserted into the cell holder with the fill line facing the user. Then results were taken in $\mathrm{mg} / \mathrm{I} \mathrm{PO}_{4}{ }^{3-13,14}$.

\subsubsection{Zinc}

Ten millilitres of the sample solution was poured into a square sample cell. With the use of a plastic dropper, $0.50 \mathrm{ml}$ of cyclohexanone was added to the solution in the graduated cylinder. Then OK was pressed on the timer. A thirty (30) second reaction period began, during the period the prepared sample in the cylinder was shaken vigorously. A colour change was observed, which depending on the zinc concentration could be reddish orange, brown or blue $2,13,16$.

\subsubsection{Sodium}

Spectrophotometry method was used, $0.50 \mathrm{ml}$ of sodium reagent $\mathrm{Na}-1 \mathrm{~K}$ was placed in a reaction cell and $0.50 \mathrm{ml}$ of the water sample added to it and mixed properly. One minute reaction time was allowed to elapse before reading the concentration of sodium from the spectrophotometer $2,12,13,16$.

\subsubsection{Magnesium}

Spectrophotometry method was used, $1 \mathrm{ml}$ of Magnesium reagent (Mg-1K) was mixed with $1 \mathrm{ml}$ of water sample and the mixture was placed in a reaction cell. The mixture was allowed to stand for 3 minutes and there after $0.30 \mathrm{ml}$ of Magnesium reagent $(\mathrm{Mg}-2 \mathrm{~K})$ was added, mixed and placed in the spectrophotometer. Magnesium concentration in the water sample was read at a wave length of $568 \mathrm{~nm}^{2,14}$.

\subsection{Bacteriological Analysis of Water Samples}

The media used for this analysis were all prepared according to manufacturer's direction and were sterilized in the autoclave at $121^{\circ} \mathrm{C}$ for fifteen minutes. Prepared media were then transferred into sterile Petri dishes $(20 \mathrm{ml}$ each) and allowed to cool before inoculation with the water samples. The stainless steel filtration unit and the glass wares used for the analyses were equally sterilized in the hot air oven at $150^{\circ} \mathrm{C}$ for one hour 2 .

\subsubsection{Inoculation Technique}

The water samples were shaken very well to mix and $100 \mathrm{ml}$ measured out of it and filtered through membrane filter $(0.45 \mu \mathrm{m}$ pore size). This filter allowed water to pass through but bacteria cells were retained on it. After filtration, the membrane filter was carefully removed with the aid of a sterile forceps and placed on the prepared molten agar. The plates were incubated for 24 hours at $37^{\circ} \mathrm{C}$, emerging colonies after the period of incubation were enumerated using a colony counter ${ }^{1,2}$.

\subsubsection{Serial Dilution}

One millilitres $(1 \mathrm{ml})$ of the water samples were pipetted into nine $(9 \mathrm{ml})$ of sterile distilled water in a separate test tube. Logarithms dilution ranging from $10^{-1}$ to $10^{-3}$ was there after made for each of the water samples. $1 \mathrm{ml}$ of the desired aliquot was transferred into a sterile petri dishes and viable plate count determined using pour plate method. Faecal and total coliform counts were performed for each sample and were inoculated in the appropriate media (i.e. MF-C agar 
and MacConkey agar). The plates were incubated at $37^{\circ} \mathrm{C}$ for 24 hours, and was observed for growth, the colony counter was used in counting the colonies, and those with $2-22 \mathrm{cfu} / \mathrm{ml}$ (colony forming unit) were counted 2,17 .

\subsubsection{Maintenance of Pure Culture}

The growth from the inoculated plates especially those from the MacConkey agar plates had mixed colonies (culture), this mix cultures were then isolated in their pure form. The bacterial representatives (i.e. from each colony) was picked and sub-cultured onto a fresh sterile nutrient agar medium. Purity of isolates was enhanced and obtained through repeated streaking on fresh plate. The colonies that was obtained now provides the pure culture of that isolates and they were maintained on nutrient agar slants as stock culture for further bacteriological analysis 2,17 .

\subsubsection{Characterization of Bacterial Isolates}

The pure bacterial isolates were characterized based on their cultural morphology and biochemical tests as reported by aAgbo et al,2; ${ }^{b A g b o}$ et al,7 and Cheesbrough ${ }^{18}$. The identification was carried out using the manual for identification of medical bacteria 2,19 . The biochemical test parameters used for characterization and identification of bacterial isolates included; Grams reaction, oxidase test, coagulase test, catalase test, Voges Proskaurer test, sugar fermentation test, motility test, and methyl-red test.

\subsection{Statistical Analysis}

Replicate readings were managed using Microsoft Excel 2010. All the replicates readings for the various analyses were subjected to one way factor analysis of variance (ANOVA). Mean values with probability values less than $0.05(\mathrm{P}<0.05)$ were considered significant at $95 \%$ level of significance while those greater than 0.05 were not significant $(P>0.05)^{20}$. Confidence interval was set as described previously by Uusippaikka ${ }^{21}$, while analysis of variance was calculated as reported by Edet et al., 20 and Nelson 22.

\section{RESULTS}

\subsection{Total Heterotrophic Bacterial Load in Water Samples}

The extent of the microbiological quality or contaminations were expressed in colony forming unit per millilitres. The results of the total heterotrophic loads in water samples from Yakurr LGA, Nigeria showed that the water sample from Ekori River had the highest total heterotrophic bacteria counts of $2.13 \pm 0.31 \times 10^{6} \mathrm{cfuml}^{-1}$. Sample A from Sokol and sample E from Kesekpang Ekori had total heterotrophic bacterial loads of $1.03 \pm 0.06 \times 10^{6} \mathrm{cfuml}^{-1}$ and $1.10 \pm 0.17 \times 10^{6} \mathrm{cfuml}^{-}$ 1 respectively.

The results also revealed that sample $C$ from Nkinforma had total heterotrophic bacterial load of $1.27 \pm 0.25 \times 10^{6} \mathrm{cfuml}^{-1}$ while sample $\mathrm{B}$ from Mgbeke Mkpani had the least total heterotrophic bacteria counts of $7.00 \pm 1.00 \times 10^{5} \mathrm{cfuml}^{-1}$. The results of the total heterotrophic bacterial loads are presented in table 1 . Superscript represents significant analysis of variance of replicate readings for each sample across the rows $(p<0.05)$. 
Table 1: Total Heterotrophic Bacteria Loads in Water Samples from Yakurr Local Government Area, Cross River State, Nigeria (x105 $\left.\mathrm{cfuml}^{-1}\right)$

\begin{tabular}{cc}
\hline Sample Code & Mean \pm SD \\
\hline SA & $10.33 \pm 0.58^{a}$ \\
SB & $7.00 \pm 1.00$ \\
SC & $12.67 \pm 2.52$ \\
SD & $21.33 \pm 3.06$ \\
SE & $11.00 \pm 1.73$ \\
\hline
\end{tabular}

Superscript represents significant analysis of variance of replicate readings for each sample across the rows $(p<0.05)$

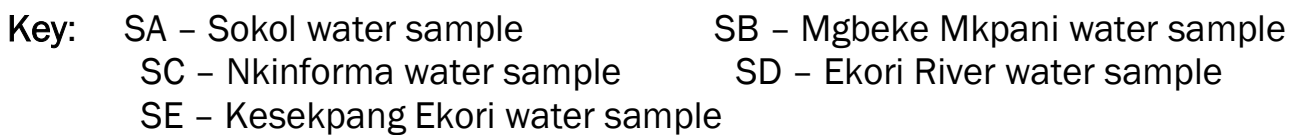

\subsection{Total Fungal Load in various Water Samples}

Water sample A from Sokol Ugep had the highest total fungal load of $1.30 \pm 0.26 \times 10^{5} \mathrm{cfuml}^{-1}$ while sample $E$ from Kesekpang Ekori had the least total fungal load of $4.67 \pm 2.52 \times 10^{4} \mathrm{cfuml}^{-1}$. Sample C from Nkinforna and sample D from Ekori River had total fungal load of $6.67 \pm 2.08 \times 10^{4} \mathrm{cfuml}^{-1}$ and $6.33 \pm 1.53 \times 10^{4} \mathrm{cfuml}^{-1}$ respectively, while sample B from Mgbeke Mkpani had total fungal load of $5.33 \pm 1.53 \times 10^{4} \mathrm{cfuml}^{-1}$. The results for the total fungal loads in various water samples from Yakurr LGA are presented in table 2. Superscript represents significant analysis of variance of replicate readings for each sample across the rows $(p<0.05)$.

Table 2: Total fungal loads on water samples from Yakurr Local Government Area, Cross River State, Nigeria $\left(\times 10^{4} \mathrm{cfuml}^{-1}\right)$

\begin{tabular}{cc}
\hline Sample Code & Mean \pm SD \\
\hline SA & $13.00 \pm 2.65^{a}$ \\
SB & $5.33 \pm 1.53$ \\
SC & $6.67 \pm 2.08$ \\
SD & $6.33 \pm 1.53$ \\
SE & $4.67 \pm 2.52$
\end{tabular}

Superscript represents significant analysis of variance of replicate readings for each sample across the rows $(p<0.05)$

$\begin{array}{ccc}\text { Key: SA - Sokol } & \text { SB - MgbekeMkpani } & \text { SC - Nkinforna } \\ \text { SD - Ekori River } & \text { SE - Kesekpang Ekori }\end{array}$ 


\subsection{Total Coliform Counts in various Water Samples}

Sample E from Kesekpang Ekori had the highest total coliform counts of $78.00 \pm 3.61 \mathrm{cfu} 100 \mathrm{ml}$ ${ }^{1}$ which was closely followed by that from Sokol ugep (sample A) with total coliform count of

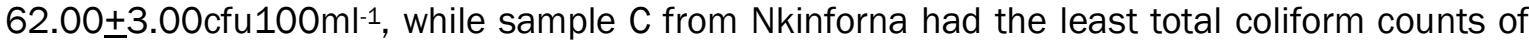
$10.00+2.00$ cfu per $100 \mathrm{ml}$. Sample B from Mgbeke Mkpani and sample D from Ekori River had a total coliform counts of $38.33 \pm 2.52 \mathrm{cfu}$ per $100 \mathrm{ml}$ and $17.00 \pm 2.00 \mathrm{cfu}$ per $100 \mathrm{ml}$ respectively. The results for the total coliform counts in water samples from Yakurr LGA are presented in table 3 . There was a significance difference across the rows $(p<0.05)$.

Table 3: Total coliform counts in water sample from Yakurr Local Government Area, Cross River State, Nigeria (Per 100ml)

\begin{tabular}{cc}
\hline Sample Code & Mean \pm SD \\
\hline SA & $62.00 \pm 3.00^{a}$ \\
SB & $38.33 \pm 2.52$ \\
SC & $10.00 \pm 2.00$ \\
SD & $17.00+2.00$ \\
SE & $78.00 \pm 3.61$ \\
\hline
\end{tabular}

Superscript represents significant analysis of variance of replicate readings for each sample across the rows $(P<0.05)$.

Key: SA-Sokol Ugep SB - Mgbeke Mkpani SC - Nkinforma SD - Ekori River SE - Kesekpang Ekori

\subsection{Biochemical Characteristics of Isolates}

The biochemical characteristics of bacterial isolates in water samples from Yakurr Local Government Area, Cross River State, Nigeria showed that a total of nine (9) bacterial isolates contaminated their water sources. These isolates were Pseudomonas aeroginosa, Escherichia coli, Bacillus subtilis, Proteus vulgaris, Serratia maecesen, Staphylococcus aureus, Salmonella spp., Enterobacter cloacae and Micrococcus leteus. The results for the biochemical characteristics of bacterial isolates in water samples from Yakurr Local Government Area are presented in table 4.

\subsection{Cultural and Morphological Characteristics of Fungal Isolates in Water Samples from Yakurr, Nigeria}

Wet mount techniques was employed in the identification of fungal isolates, having carefully compared the macroscopic and microscopic features with a mycology standard Manuel for identification of fungal isolates as shown in table 5. The fungal isolates encountered in the course of the research were: Penicillium sp., Mucor sp., Aspergillus sp., Rhizopus sp. and Fusarium sp. 
Table 4: Biochemical Characteristics of Bacterial Isolates in Water Samples from Yakurr LGA, Cross River State, Nigeria

\begin{tabular}{|c|c|c|c|c|c|c|c|c|c|c|c|c|c|c|c|c|c|c|c|}
\hline 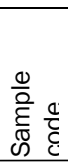 & $\begin{array}{l}\sum_{2}^{0} \\
0 \\
\stackrel{0}{0} \\
0 \\
\underline{0}\end{array}$ & Cultural Characteristics & Shape & $\frac{\frac{\varepsilon}{\sigma}}{\frac{d}{U}}$ & 晋 & $\begin{array}{l}\frac{0}{0} \\
\text { 음 }\end{array}$ & $\frac{0}{\mathbb{\pi}}$ & 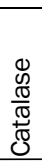 & $\begin{array}{l} \pm \\
\infty \\
\frac{\pi}{0} \\
\frac{0}{x}\end{array}$ & 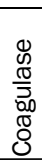 & $\begin{array}{l}\Phi \\
\mathscr{W} \\
\overparen{D} \\
\stackrel{Ð}{\supset}\end{array}$ & 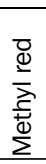 & 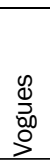 & 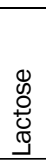 & 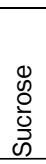 & 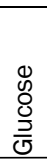 & 里 & 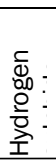 & $\begin{array}{l}\text { Probable } \\
\text { organism }\end{array}$ \\
\hline \multirow[t]{3}{*}{ SA } & 1 & $\begin{array}{l}\text { Raised, smooth, } \\
\text { circular and greenish } \\
\text { pigmented }\end{array}$ & Curved rod & - & + & - & + & + & + & - & - & + & - & - & - & - & - & - & $\begin{array}{l}\text { Pseudomonas } \\
\text { aeroginosa }\end{array}$ \\
\hline & 2 & $\begin{array}{l}\text { Mucoid, opaque, } \\
\text { circular, convex and } \\
\text { smooth colony }\end{array}$ & Short rod & - & + & + & - & + & - & - & - & + & - & + & + & + & + & - & Escherichia coli \\
\hline & 3 & $\begin{array}{l}\text { Large, irregular, dry flat } \\
\text { colony }\end{array}$ & Bacilli rod & + & + & - & + & + & + & - & - & - & + & - & - & + & - & + & Bacillus subtilis \\
\hline \multirow[t]{3}{*}{ SB } & 1 & $\begin{array}{l}\text { Swarming, flat, smooth } \\
\text { and moist }\end{array}$ & $\begin{array}{l}\text { Small tiny } \\
\text { rod }\end{array}$ & + & + & - & + & + & - & - & + & + & - & + & + & + & - & + & Proteus vulgaris \\
\hline & 2 & $\begin{array}{l}\text { Circular, spreading, } \\
\text { raised and red } \\
\text { pigmented colony }\end{array}$ & $\begin{array}{l}\text { Rod, some } \\
\text { in chain }\end{array}$ & - & + & - & + & - & - & - & - & - & + & - & - & + & - & - & Seratiamarcesen \\
\hline & 3 & $\begin{array}{l}\text { Mucoid, circular, } \\
\text { convex and smooth } \\
\text { colony }\end{array}$ & Short rod & - & + & + & - & + & - & - & - & + & - & + & + & + & + & - & Escherichia coli \\
\hline \multirow[t]{3}{*}{ SC } & 1 & $\begin{array}{l}\text { Translucent, smooth, } \\
\text { raised circular colony }\end{array}$ & $\begin{array}{l}\text { Cocci in } \\
\text { cluster }\end{array}$ & + & - & - & - & + & - & + & - & - & + & - & - & + & - & - & $\begin{array}{l}\text { Staphylococcus } \\
\text { aureus }\end{array}$ \\
\hline & 2 & $\begin{array}{l}\text { Raised, pink with black } \\
\text { centre }\end{array}$ & $\begin{array}{l}\text { Capsulated } \\
\text { rod }\end{array}$ & - & + & - & + & + & - & - & + & + & - & - & - & + & - & + & Salmonella spp \\
\hline & 3 & $\begin{array}{l}\text { Smooth, grey } \\
\text { pigmented and moist } \\
\text { colony }\end{array}$ & Single rod & - & + & - & + & + & - & - & - & - & + & + & + & + & + & - & $\begin{array}{l}\text { Enterobactercloa } \\
\text { cae }\end{array}$ \\
\hline \multirow[t]{4}{*}{ SD } & 1 & $\begin{array}{l}\text { Mucoid, opaque, } \\
\text { circular, smooth colony }\end{array}$ & Short rod & - & + & + & - & + & - & - & - & + & - & + & + & + & + & - & Escherichia coli \\
\hline & 2 & $\begin{array}{l}\text { Rod, circular spreading } \\
\text { colony }\end{array}$ & Rod & - & + & - & + & - & - & - & - & - & + & - & - & + & - & - & Seratiamarcesen \\
\hline & 3 & $\begin{array}{l}\text { Raised, smooth, } \\
\text { circular, greenish } \\
\text { colony }\end{array}$ & Curved rod & - & + & - & + & + & + & - & - & + & - & - & - & - & - & - & $\begin{array}{l}\text { Pseudomonas } \\
\text { aeroginosa }\end{array}$ \\
\hline & 4 & $\begin{array}{l}\text { Bright yellow, moist and } \\
\text { smooth colony }\end{array}$ & $\begin{array}{l}\text { Cocci in } \\
\text { pairs }\end{array}$ & + & - & - & + & + & + & - & - & + & - & - & - & + & - & - & $\begin{array}{l}\text { Micrococcus } \\
\text { leutus }\end{array}$ \\
\hline
\end{tabular}

Table 5: Cultural and morphological characteristics of fungal isolates

\begin{tabular}{|c|c|c|c|c|c|c|}
\hline $\begin{array}{l}\text { Sample } \\
\text { Code }\end{array}$ & $\begin{array}{l}\text { Isolate } \\
\text { Number }\end{array}$ & $\begin{array}{l}\text { Colour of } \\
\text { Aerialhyphae }\end{array}$ & $\begin{array}{l}\text { Colour of } \\
\text { Substrate } \\
\text { Hyphae }\end{array}$ & $\begin{array}{l}\text { Nature of } \\
\text { Hyphae }\end{array}$ & Spore Shape & $\begin{array}{l}\text { Probable } \\
\text { Organisms }\end{array}$ \\
\hline SA & $\begin{array}{l}1 \\
2\end{array}$ & $\begin{array}{l}\text { Green } \\
\text { Dark }\end{array}$ & $\begin{array}{l}\text { Brown } \\
\text { White }\end{array}$ & $\begin{array}{l}\text { Senate } \\
\text { Aseptate }\end{array}$ & $\begin{array}{l}\text { Round Sporangium } \\
\text { Round Sporangium }\end{array}$ & $\begin{array}{l}\text { Penicillin } \\
\text { gabrium } \\
\text { Mucor } \\
\text { indicus }\end{array}$ \\
\hline SB & $\begin{array}{l}1 \\
2 \\
3\end{array}$ & $\begin{array}{l}\text { Green } \\
\text { Yellow } \\
\text { Dark }\end{array}$ & $\begin{array}{l}\text { Brown } \\
\text { Dark } \\
\text { Brown } \\
\text { White }\end{array}$ & $\begin{array}{l}\text { Senate } \\
\text { Sepate } \\
\text { Aseplate }\end{array}$ & $\begin{array}{l}\text { Round Sporangium } \\
\text { Oval Conidia } \\
\text { RomdSporagium }\end{array}$ & $\begin{array}{l}\text { Penicillin } \\
\text { sporangium } \\
\text { Asporgillus } \\
\text { niger } \\
\text { Mucor } \\
\text { indicus }\end{array}$ \\
\hline SC & $\begin{array}{l}1 \\
2\end{array}$ & $\begin{array}{l}\text { Dark } \\
\text { Shades of } \\
\text { White }\end{array}$ & $\begin{array}{l}\text { White } \\
\text { Dark }\end{array}$ & $\begin{array}{l}\text { Aseplate } \\
\text { Non- } \\
\text { seplate }\end{array}$ & $\begin{array}{l}\text { Romd Sporangium } \\
\text { Romd Sporangium }\end{array}$ & $\begin{array}{l}\text { Muco } \\
\text { rindicus } \\
\text { Rlizonus spp }\end{array}$ \\
\hline SD & $\begin{array}{l}1 \\
2\end{array}$ & $\begin{array}{l}\text { Yellow } \\
\text { Green }\end{array}$ & $\begin{array}{l}\text { Dark } \\
\text { Brown }\end{array}$ & $\begin{array}{l}\text { Seplate } \\
\text { Seplate }\end{array}$ & $\begin{array}{l}\text { Oval Conidia } \\
\text { Round Sporangium }\end{array}$ & $\begin{array}{l}\text { Asporgillus } \\
\text { niger }\end{array}$ \\
\hline
\end{tabular}




\begin{tabular}{|c|c|c|c|c|c|c|}
\hline & 3 & White & $\begin{array}{l}\text { Brown } \\
\text { Dark }\end{array}$ & $\begin{array}{l}\text { Non- } \\
\text { seplate }\end{array}$ & Round Sporangium & $\begin{array}{l}\text { Penicillium } \\
\text { indicus } \\
\text { Rlizopus spp }\end{array}$ \\
\hline \multirow[t]{2}{*}{ SE } & 1 & Pink & Dark & Sentate & Concave & Fusarium spp \\
\hline & 2 & Green & $\begin{array}{l}\text { Brown } \\
\text { Brown }\end{array}$ & Sentate & Round Sporangium & $\begin{array}{l}\text { Aspergillus } \\
\text { niger }\end{array}$ \\
\hline
\end{tabular}

Key: SA - SokolUgep SB - MgbekeMkpani SC - Nkinforma SD - Ekori River SE - KesekpangEkori spp - Species 3.6 Physico-chemical Properties of Various Water Samples

The physico-chemical properties of the different water samples from Yakurr Local government Area, Cross River State, Nigeria are as shown in table 6. The result revealed that the water sample from Kesekpong Ekori had the lowest $\mathrm{pH}$ and turbidity value of $5.00 \pm 0.02$ and 3.05+0.01NTU. Sample A from Solok Ugep had the highest electrical conductivity value of $72.76 \pm 0.01 \mu \mathrm{s} / \mathrm{cm}$ while sample $\mathrm{D}$ from Ekori River had the least electrical conductivity value of $29.01 \pm 0.01 \mu \mathrm{s} / \mathrm{cm}$.

Of all the water samples collected, sample A from Solok Ugep had the highest $\mathrm{BOD}_{5}$ value of $10.00 \pm 0.01 \mathrm{mg} / \mathrm{I}$ while sample $\mathrm{E}$ from Kesekpong Ekori had the least $\mathrm{BOD}_{5}$ value of $6.59 \pm 0.03 \mathrm{mg} / \mathrm{l}$. Sample A also had the highest magnesium content with value of $18.08 \pm 0.02 \mathrm{mg} / \mathrm{I}$ while sample $\mathrm{C}$ had the least magnesium content with value of $9.91 \pm 0.03$. The full results of the Physico-chemical properties of water samples from Yakurr Local Government Area, Cross River State, Nigeria are presented in table 6. Similar superscript represents significant analysis of variance of replicate readings for each sample across the columns for each sampling station $(p<0.05)$.

Table 6: Physicochemical Properties of Water Samples from Yakurr Local Government Area of Cross River State, Nigeria 


\begin{tabular}{|c|c|c|c|c|c|c|c|c|}
\hline S/No & Parameters & Units & 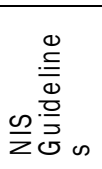 & $\begin{array}{l}\text { Solok Ugep } \\
\text { (A) }\end{array}$ & $\begin{array}{l}\text { Mgbeke } \\
\text { Mkpani } \\
\text { (B) }\end{array}$ & $\begin{array}{l}\text { Nkin Fornaassi } \\
\text { (C) }\end{array}$ & $\begin{array}{l}\text { Ekori River } \\
\text { (D) }\end{array}$ & $\begin{array}{c}\text { Kesekpong E } \\
(E)\end{array}$ \\
\hline 1 & Temperature & ${ }^{\circ} \mathrm{C}$ & Ambient & $27.88 \pm 0.02^{\mathrm{a}}$ & $27.00 \pm 0.02^{a}$ & $26.90 \pm 0.02^{a}$ & $27.01 \pm 0.01^{\mathrm{a}}$ & $27.11 \pm 0.01$ \\
\hline 2 & $\mathrm{pH}$ & & $6.5-8.5$ & $6.38 \pm 0.03$ & $6.01 \pm 0.01$ & $5.69 \pm 0.02$ & $5.50 \pm 0.01$ & $5.00 \pm 0.02$ \\
\hline 3 & Turbidity & NTU & 5.0 & $10.18 \pm 0.03$ & $5.54 \pm 0.02$ & $4.51 \pm 0.02$ & $30.41 \pm 0.01$ & $3.05 \pm 0.01$ \\
\hline 4 & Electrical conductivity & $\mu S / c m$ & 500 & $72.76 \pm 0.01$ & $38.84 \pm 0.02$ & $35.87 \pm 0.03$ & $29.01 \pm 0.01$ & $39.45 \pm 0.0$ \\
\hline 5 & $\begin{array}{l}\text { Total dissolved solids } \\
\text { (TDS) }\end{array}$ & mg/l & 1000 & $43.63 \pm 0.03$ & $23.29 \pm 0.04$ & $21.51 \pm 0.01$ & $18.24 \pm 0.01$ & $21.86 \pm 0.0$ \\
\hline 6 & Aluminium & $\mathrm{mg} / \mathrm{l}$ & 0.02 & $0.00 \pm 0.00$ & $0.00 \pm 0.00$ & $0.00 \pm 0.00$ & $0.00 \pm 0.00$ & $0.00 \pm 0.0 \mathrm{C}$ \\
\hline 7 & Ammonia $\mathrm{NH}_{3}-\mathrm{N}$ & $\mathrm{mg} / \mathrm{l}$ & 0.05 & $0.25 \pm 0.02$ & $0.21 \pm 0.01$ & $0.24 \pm 0.01$ & $0.34 \pm 0.01$ & $0.20 \pm 0.01$ \\
\hline 8 & Nickel & $\mathrm{mg} / \mathrm{l}$ & 0.01 & $0.00 \pm 0.00$ & $0.00 \pm 0.00$ & $0.00 \pm 0.00$ & $0.24 \pm 0.01$ & $0.00 \pm 0.0 C$ \\
\hline 9 & Calcium Ca & $\mathrm{mg} / \mathrm{l}$ & 50 & $10.08 \pm 0.03$ & $7.00 \pm 0.03$ & $7.20 \pm 0.02$ & $6.01 \pm 0.02$ & $6.59 \pm 0.0 \Xi$ \\
\hline 10 & Zinc & $\mathrm{mg} / \mathrm{l}$ & 5.0 & $0.19 \pm 0.02$ & $0.30 \pm 0.02$ & $0.10 \pm 0.01$ & $0.24 \pm 0.01$ & $0.14 \pm 0.01$ \\
\hline 11 & Salinity & Ppm & 4000 & $30.04 \pm 0.01$ & $19.66 \pm 0.02$ & $17.25 \pm 0.01$ & $13.94 \pm 0.02$ & $19.01 \pm 0.0$ \\
\hline 12 & Chromium & $\mathrm{mg} / \mathrm{l}$ & 0.01 & $0.06 \pm 0.01$ & $0.01 \pm 0.01$ & $0.03 \pm 0.01$ & $0.02 \pm 0.01$ & $0.01 \pm 0.01$ \\
\hline 13 & Ammonium $\mathrm{NH}_{4}-\mathrm{N}$ & $\mathrm{mg} / \mathrm{l}$ & - & $0.29 \pm 0.01$ & $0.21 \pm 0.01$ & $0.26 \pm 0.01$ & $0.35 \pm 0.01$ & $0.21 \pm 0.01$ \\
\hline 14 & Copper & $\mathrm{mg} / \mathrm{l}$ & 1.0 & $0.06 \pm 0.01$ & $0.00 \pm 0.00$ & $0.11 \pm 0.01$ & $0.00 \pm 0.00$ & $0.00 \pm 0.0 C$ \\
\hline 15 & BOD & $\mathrm{mg} / \mathrm{l}$ & 14 & $10.00 \pm 0.01$ & $7.99 \pm 0.04$ & $8.60 \pm 0.02$ & $10.69 \pm 0.01$ & $6.00 \pm 0.02$ \\
\hline 16 & Total Chlorine & $\mathrm{mg} / \mathrm{l}$ & 0.5 & $0.00 \pm 0.00$ & $0.00 \pm 0.00$ & $0.00 \pm 0.00$ & $0.00 \pm 0.00$ & $0.00 \pm 0.0 C$ \\
\hline 17 & Free Chlorine & $\mathrm{mg} / \mathrm{l}$ & 0.2 & $0.00 \pm 0.00$ & $0.00 \pm 0.00$ & $0.00 \pm 0.00$ & $0.00 \pm 0.00$ & $0.00 \pm 0.0 C$ \\
\hline 18 & Total Hardness & $\mathrm{mg} / \mathrm{l}$ & 100 & $34.19 \pm 0.03$ & $17.05 \pm 0.05$ & $17.11 \pm 0.01$ & $17.11 \pm 0.01$ & $17.10 \pm 0.0$ \\
\hline 19 & Iron Fe & $\mathrm{mg} / \mathrm{l}$ & 0.3 & $1.51 \pm 0.01$ & $1.00 \pm 0.01$ & $0.55 \pm 0.01$ & $0.67 \pm 0.01$ & $0.32 \pm 0.01$ \\
\hline 20 & Phosphorus $\mathrm{P}$ & $\mathrm{mg} / \mathrm{l}$ & - & $5.39 \pm 0.03$ & $3.20 \pm 0.02$ & $3.10 \pm 0.02$ & $5.00 \pm 0.02$ & $3.51 \pm 0.01$ \\
\hline 21 & Phosphate $\mathrm{PO}_{4}$ & $\mathrm{mg} / \mathrm{l}$ & 250 & $13.69 \pm 0.02$ & $7.47 \pm 0.03$ & $7.01 \pm 0.02$ & $15.70 \pm 0.02$ & $7.90 \pm 0.02$ \\
\hline 22 & Manganese & $\mathrm{mg} / \mathrm{l}$ & 0.5 & $0.11 \pm 0.01$ & $0.08 \pm 0.01$ & $0.09 \pm 0.01$ & $0.15 \pm 0.01$ & $0.09 \pm 0.01$ \\
\hline 23 & Magnesium-Mg & $\mathrm{mg} / \mathrm{l}$ & 20 & $18.08 \pm 0.02$ & $10.07 \pm 0.02$ & $9.91 \pm 0.03$ & $11.06 \pm 0.06$ & $11.50 \pm 0.0$ \\
\hline 24 & Nitrogen - N & $\mathrm{mg} / \mathrm{l}$ & 0.5 & $0.21 \pm 0.01$ & $0.16 \pm 0.01$ & $0.20 \pm 0.01$ & $0.27 \pm 0.01$ & $0.18 \pm 0.01$ \\
\hline 25 & Sulfide & $\mathrm{mg} / \mathrm{l}$ & 0.1 & $0.00 \pm 0.00$ & $0.00 \pm 0.00$ & $0.00 \pm 0.00$ & $0.00 \pm 0.00$ & $0.00 \pm 0.0 C$ \\
\hline
\end{tabular}

\section{DISCUSSION}

Water sources used for drinking and domestic use in Yakurr Local Government Area in Cross River State, Nigeria was found to be surface water which are the river and streams and underground source such as borehole. Out of five (5) water sources sampled in the LGA, three were fit for consumption and that was Mgbeke Mkpani, Kesekpang Ekori and Nkinforna Assiga. The other two sources of water were found to be bacteriological unfit for human consumption because they contain indicator organisms. The indicator organisms are made up of coliforms in which Escherichia coli was found in large numbers per $100 \mathrm{ml}$ of the water sample analyzed. Okorafor et al, ${ }^{1}$ and a Agbo et al, ${ }^{2}$ in a similar research in Calabar, detected no coliform in the drinking water sources they sampled.The levels of indicator bacteria per $100 \mathrm{ml}$ of water were more than the established standards ${ }^{23}$. From the coliform count there was evidence of faecal contamination. The total viable count for sample A Sokol Ugep was $1.03 \pm 0.06 \times 10^{6} \mathrm{cfuml}^{-1}$ this can be attributed to the villagers constant washing of their clothes and bedding in the stream.

The physical and environmental condition of this quality of water contributed to their nonsanitary conditions. Out of the entire organisms isolated from these sources, Escherichia coli and Bacillus $s p$ were predominant. Isolates from this research were similar to that isolated by Okorafor et al, 1 and aAgbo et $a{ }^{2},{ }^{2}$. Bacteria are found everywhere in nature except within the 
tissues of healthy animals and plants and in the deep layers of the earth. The total coliform count for sample B which was Mgbeke Mkpani was $38.33 \pm 2.52 \mathrm{cfu} / 100 \mathrm{ml}$ of water. This is to shows that fetching of water by many people is accomplished by introduction of coliforms. The total viable count of coliform for sample $C$ which was Nkinforna was $10.00 \pm 2.00 \mathrm{cfu}$ per $100 \mathrm{ml}$. This could be attributed to the activities of the villagers while fetching water from the stream. During the study it was noticed that some of them used dirty buckers to fetch the water. These contributed to high number of microbial loads.

The total viable coliform count for sample D which was Ekori River was $17.00 \pm 2.00$ cfu per $100 \mathrm{ml}$. This could be attributed to the activities of the communities while fetching water with their dirty hand etc. The presence and high number of faecal coliforms in most of the water samples analysed showed that there were faecally contaminated, this agreed with the findings of Okorafor et al,1. Total viable count for coliform for sample E which was Kesekpang Ekori was $78.00 \pm 3.36 / 100 \mathrm{ml}$. This have the highest total coliform count because the community members used to wash their clothes and fetch water with their dirty vessels, the coliform count for this particular stream shows that a correlation with of the total viable count against the recovering of coliforms including Escherichia coli shown that the contamination was due to a recent factor.

It was very clear that the degree of microbiological contamination of Sokol Ugep, Ekori River are higher than that recommended by World Health Organization standard 8. The correlation between the general microbial count and the total coliform count shows that the same factors control both parameters. This report was consistent with the finding of Antai \& Anozie ${ }^{24}$. The transmission through contaminated water supply is by far most serious of infection and was responsible for the more serious enteric disease particularly cholera and typhoid fever. From this research study, drinking water obtained from Sokol Ugep and Ekori River are unfit for drinking due to non-sanitary conditions, and incidence of disease can be evidence of the water contamination.

The $\mathrm{pH}$ of the water samples showed that the $\mathrm{pH}$ of Nkin Fornaassi stream water sample and Ekori River water sample was below that of the WHO standard. This findings is in variance with that of aAgbo et al,2 but agrees with the findings of Okorafor et al,1. The turbidity of Ekori River water sample was far above the WHO standard and NIS guideline, this result is contrary to that of Okorafor et al, ${ }^{1}$ and aAgbo et al, ${ }^{2}$ while Aluminium was not detected in all the water samples. The Manganese concentration of all the water samples was far below that of the NIS standard which was a good one while the Magnesium concentration of Sokol Ugep was slightly close to that of the NIS standard.

For all the five sources analyzed, none have received any treatment. It is surprising that none of the water sources analyzed met the chemical standard recommended by World Health Organization for drinking purposes 23 . Biochemical characteristics of isolate from the research study revealed that there were ten (10) Gram-negative rods and five (5) Gram-positive rods. Most of the physico-chemical parameters had values which conform to the WHO standard for drinking water ${ }^{9}, 23$. However, the high concentration of some parameters such as manganese, iron, lead and turbidity depict possible pollution.

\section{RECOMMENDATIONS}


To drastically reduce health problems associated with water pollution by waste and fecal materials in Yakurr Local Government Area, Cross River State, Nigeria. It is necessary to educate the villagers about the desirable quality of potable water and faecal matter into the river and streams.

$>\quad$ The villagers should be prevented from turning the water ways into toilet.

$>\quad$ Water fetched from these contaminated sources, should be treated by boiling and filter it before being use for domestic consumption.

$>\quad$ Government should help and make pipe borne water available which is practically treated before distributions and use.

$>\quad$ Routine assessment and bacteriological examination of water sources show be carried out to ascertain the extent of contamination with the aim of eliminating the contaminants.

\section{CONCLUSION}

The evaluation of drinking water quality in Yakurr, Cross River State, Nigeria has enable one to estimate the poor quality of water present in the communities found in the local government area. However, some of the water samples are bacteriological fit for drinking and other domestic use. The use of bacterial indicators of faecal pollution are the coliforms groups as a whole and particularly E. coli. The result clearly showed that samples from three (3) sources were of W.H.O standards while other sources were unsuitable for human consumption as well as for domestic use.

\section{REFERENCES}

1. Okorafor KA, Agbo BE, Johnson AM, Chiorlu M. Physico-chemical and Bacteriological Characteristics of Selected Streams and Boreholes in Akamkpa and Calabar Municipality, Nigeria. Archives of Applied Science Research 2012; 4 (5): 2115-2121

2. aAgbo BE, Ogar AV, Akpan UL, Mboto Cl. Physico-Chemical and Bacteriological Quality of Drinking Water Sources in Calabar Municipality, Nigeria. Journal of Advances in Microbiology 2019; 14 (4): 1-22

3. Onuh CA, Gongchi LC. The incidence of Enteric Bacteria in Drinking Water from Mangu Local Government Area, Plateau State, Nigeria. African Journal of Natural Sciences 1998; 2 (2): 115-119.

4. APHA - AWWA, Standard Methods for the Examination of Water and Waste- water, 19th Edition. Washington: American Publication Health Association, 1998 pp. 136.

5. Food and Agriculture Organization (FAO). Chemical Analysis Manual for Food and Water 5th Edition, Rome: FAO Press 1997 pp. 20-26.

6. Cosgrove WJ, Rijsberman FR. World Water Vision: Making water everybody's Business. UK: Earthscan Publication Ltd., 2000 pp.108.

bAgbo BE, Ogar AV, Itah AY, Brooks AA, Akonjor MA. Assessment of the effects of cassava mill effluent on the soil and its microbiota in Biase Local Government Area of Cross River State, Nigeria. World Journal of Advanced Research and Reviews 2019; 1 (2): 034-044

7. World Health Organization (WHO). Drinking Water Guidelines; Bacteriological Parameters. Geneva: World Health Organization 2002.

8. World Health Organization (WHO). Standard methods for the examination of water and waste water in: Guidelines for drinking water quality, $2^{\text {nd }}$ Edition, volume 2. Geneva: World Health Organization 2007. 
9. Adegoke O, Adebayo BE, Olugbenga OE, Sunday UK, Nchedo C. Microbiological examination of sachet water sold in Aba, Abia State, Nigeria. Global Research Journal of Microbiology 2012; 2 (1): 062-066.

10. Brooks AA, lyakndue ML, Unimke AA, Agbo BE. Rubber Effluent Bio-Analyses and Its Impacts on the Microbial Community Structure of the Soil in Calabar, Nigeria. Asian Journal of Environment \& Ecology 2017; 4 (3): 1-9.

11. Digha ON, Ekanem JD. Effects of Population Density on Water Quality in Calabar Municipality Cross River State, Nigeria. Journal of Environment and Earth Science 2015; 5(2): 7-21

12. lyakndue ML, Brooks AA, Unimke AA, Agbo BE. Effects of palm oil mill effluent on soil microflora and fertility in Calabar-Nigeria. Asian Journal of Biology 2017; 2 (3): 111.

13. Okwute LO, Isu NR. The environmental impact of palm oil mill effluent (POME) on some physicochemical parameters and total aerobic bio-land of soil at a dump site in Anyigbe, Kogi State, Nigeria. African Journal of Agricultural Research 2007; 2 (12): 656-662.

14. Ekpo IA, Agbor RB, Albert PE, Okpako EC, Inyang PI. Assessment of Heavy Metal Status and Bacteria Population in Municipal Borehole Water in Landfill and NonLandfill Areas in Calabar Municipality, Cross River State, Nigeria. International Journal of Engineering and Applied Sciences 2013; 2(4): 31-41

15. Ogunmodede OT, Ajayi OO, Amoo IA, Adewole E. Characterization of Dumpsite: Case study of Ado-Ekiti and ljero Ekiti, Nigeria. Journal of Environmental Science, Toxicology and Food Technology 2013; 3 (6): 43-50.

16. Ikpoh IS, Lennox JA, Ekpo IA, Agbo BE, Henshaw EE, Udoekong NS. Microbial quality assessment of Kunu beverage locally prepared and Hawked in Calabar, Cross River State, Nigeria. Global Journal of Biodiversity Science and Management 2013; 3 (1): 58-61.

17. Cheesbrough M. Biochemical test to identify bacteria in: District laboratory practice in tropical countries Part 2. UK: Cambridge University Press, 2006 pp 63-70.

18. Cowan ST, Steel KJ. Manual for the identification of medical bacteria. UK: Cambridge University Press, 1985 pp 45-60.

19. Edet UO, Antai SP, Brooks AA, Asitok AD. Microbiological Examination and Physicochemical Analysis of Estuary Water Used as a Point of Source Drinking Water. International Journal of Pathogen Research 2018; 1:1-13

20. Uusipaikka E. Exact simultaneous confidence intervals for multiple comparison amongst three or four mean values. Journal of the American Statistical Association 1985; 80: 111-127.

21. Nelson PR. A comparison of samples sizes for the analysis of means and analysis of variance. Journal of Quality Technology 1983; 15: 33-39.

22. World Health Organization (WHO). Global Cost and Benefits of drinking water supply and sanitation intervention to reach the target and universal coverage, Geneva: World Health Organization 2012.

23. Antai SP, Anozie SO. Incidence of Infantile Diarrhoea due to Enteropathogenic Escherichia coli in Port-Harcourt Metropolis. Journal of Applied Bacteriology 1987; 62 (3): 227-229. 